\title{
THE ORGANIZATION OF MANAGEMENT ACCOUNTING AT SMALL ENTERPRISES IN UKRAINE
}

\author{
Nadiya KHOCHA ${ }^{1}$ \\ Ivan Franko National University of Lviv, Ukraine
}

\begin{abstract}
The purpose of the research is to study the organization of managerial accounting in Ukrainian small enterprises. Methodology. The survey of management accounting is conducted by an interview with the manager/ chief accountant/financial director of small enterprises, or by sending the questionnaires to these persons via the e-mail. The sample of study includes fifty-five small enterprises of the Lviv region in different types of activities and forms of ownership. Results. Analysis of theoretical base of Ukrainian scholars and the experience of management accounting in foreign small enterprises allowed distinguishing three main stages of the study. Summarizing the results of the survey, received on the base of the questionnaire of the first stage "Information for management decision-making", we can conclude that the main source of information for the manager in making managerial decisions are the operational reports or their combination with financial assessment; the preparation of such information is made by chief accountant (outsourcer), who submits it to the chief manager daily, once per week or month. The indicators of financial reporting, analytical information, obtained on the base of management accounting methods, as well as non-financial indicators that characterize the economic activities of a small enterprise, are the basis for managers in managerial decision-making. The results of the second stage "Practice of conducting the management accounting" show that, in order to improve the financial position of small enterprises, their managers use information derived from the application of methods of operational and strategic management accounting. However, the level of their implementation is rather low since most small entities use only one of the methods of operational and strategic management accounting. It is defined that the number of management accounting methods used by small enterprises is higher if the founders are foreign citizens and/or whose average number of employees exceeds 30 persons. Significant money and time expenditures for the organization and conducting of the management accounting are the main reason for the refusal to use it at small enterprises, due to the results of the third phase of the research "Reasons for the refusal from the management accounting and organization of management accounting". Otherwise, most of the small enterprises have an understanding of the benefits from using management accounting, as well as do not deny the expediency of its organization and determine the methods of managerial accounting, which will help to improve their financial situation. Practical implications. The results of the study confirmed that a sufficient part of the management informational support at small enterprises of Lviv region is the information obtained by the use of methods and tools of managerial accounting. However, we can observe a low level of their application. Therefore, appears a need to ensure the awareness of managers on the benefits of using different management accounting methods, which can be achieved by attending specialized courses, trainings or seminars conducted on the base of higher education institutions. Value/originality. The results of the study are the framework for the creation a theoretical base of managerial accounting for Ukrainian small business entities and mechanisms of its implementation in practice.
\end{abstract}

Key words: small enterprise, management accounting, tools, methods, organization.

JEL Classification: L25, M40, M41

\section{Introduction}

The modern economic conditions stimulate small businessentitiestofind theeffectivewaysofthecompany's profit increase that is possible in the situation of properly provided information support of management system. The necessary, objective, and up-to-date information can be provided by an accounting system that generates information flows related to the small business activities. First of all, it relates to information support created by the use of management accounting methods and tools. On the other hand, general principles of management accounting, approaches and types of its

Corresponding author:

${ }^{1}$ Department of Accounting and Audit, Ivan Franko National University of Lviv.

E-mail: nkhocha@ukr.net 
organization have not been yet sufficiently developed at the theoretical level. Moreover, scientists have not yet reached the consensus regarding the possibility of its adaption at small enterprises.

A significant reason for the insufficient use of management accounting tools at small enterprises is the opinion of some professionals about the need to use it only at large enterprises. That is to say, L. Chernelevskyy (2003) argues that the use of such management accounting method as budgeting is not relevant for small enterprises since they have mainly produced a small range of products and there is one or maximum two centres of responsibility, which are identical to cost centres. T. Slozko (2006) and S. Levytska (2007) are convinced that management accounting should be implemented in medium and large enterprises. They argued this position by the fact that small business entities have a narrow range of activity, a small number of accounting officers and, in some cases, the accounting has been doing by the manager or a specialized accounting organization, which leads to conducting the only statutory financial accounting.

However, regardless the size of the company, its manager needs to receive the information in time about: a kind of the most profitable activity; products which are most profitable and in high demand (about the costs of production, the revenue of realization in the future); a formation of a breakeven assortment of production; buyers and suppliers who occupied the largest segment in the realization and supply of the enterprise.

These and other issues stimulate managers to implement a subsystem of management accounting for small enterprises, as well as scientists to create a theoretical framework and to look for the best options of using the management accounting tools for this category of enterprises.

\section{Theoretical researches of the management accounting organization at small enterprises in Ukraine}

The problems of management accounting organization at a small enterprise are described in the works of some Ukrainian scientists: E.M. Lymonova, S.M. Denga, S.I. Drobyazko, T.A. Gogol, N.I. Niporko, L.M. Ocheret'ko, N.V. Krasovska.

E.M. Lymonova (2005) considers that one of the conditions for conducting the high-quality controlling at a small enterprise is the organization of managerial accounting. The scientist offers to create an integrated model of management accounting on the base of financial and managerial accounting. As a background for this model is proposed to use an accounting system of partial costing (direct costing system), which considers the calculation of the cost of products or services based on the division on fixed and variable costs. Such costs' division will be used to determine the margin revenue, as a result of comparing the sales revenue from a certain period with variable costs. The priority activities or products for the manager should be those, which marginal income is enough to cover the constant costs and to receive profit.

S.I. Drobyazko (2013) proposes to use at the small enterprises an integrated monistic system of linked financial and managerial accounting, in which analytical accounting and correspondence of accounts are organized in such a way that information for management accounting is derived from financial accounting data. Moreover, a scientist defines the principles of preparation and the composition of managerial reporting of small business enterprises.

S.M. Denga (2007) mentioned the necessity of the financial and managerial accounting integration at small enterprises. With this aim, it is necessary to add the financial chart of accounts by accounting nomenclature and analytical accounts for the goals of the management accounting. In particular, the scientist offers such a system of accounting nomenclature and analytical accounts to the accounts of income, expenses, and financial results of the general chart of accounts for trading enterprises, which can be realized in the information system of financial accounting, in particular, "1C: Enterprise".

T.A. Gogol (2014) explores the process of managerial accounting implementation at small enterprises. In particular, the scientist outlines the basic principles (simplicity, accessibility, and clarity), construction requirements and factors that influence the organization of the subsystem of management accounting at small enterprises, as well as develop a methodology for the formation and compilation of management reporting.

N.I. Niporko (2015) developed an algorithm of managerial accounting implementation at a small enterprise, which includes four stages: analytical, methodological, organizational, as well as the stage of documentation and automatization.

L.M. Ocheretko and N.V. Krasovska (2017) proposed a process of management accounting implementation in small businesses that use a simplified form of accounting.

Thus, the main directions of Ukrainian scientists' researches have the theoretical character and are related to the justification of the feasibility of implementation of a system of managerial accounting for small enterprises, studying the problems in this process, defining the factors and stages of the system formation. In view of this, it is important to study the practice of management accounting at small- and medium-sized enterprises (hereinafter: SMEs) abroad and in Ukraine.

\section{The practice of management accounting at small enterprises abroad}

We will try to perform some researches conducted in Canada, European Union member states (Great 
Britain, Finland, Italy, Croatia, Slovakia, and Bulgaria), countries of Southeast Asia (Malaysia, Philippines) and Kenya. The significance of investigations lies in their applied nature. The object of these studies is the process of management accounting at small- and mediumsized enterprises of different types of activities. The sample was carried out from 1 enterprise in Finland to 397 enterprises in Slovakia. The interviews were conducted at the SMEs of one city (Philippines), as well as in selected regions (Canada, Bulgaria, Croatia) and the entire country (Great Britain, Italy, Slovakia, Malaysia, Kenya) by conducting the interviews with owners/managers of enterprises, or by sending questionnaires to postal or e-mail addresses.

The study of management accounting practices was conducted with the consideration of various aspects of SMEs activity in different countries (see: Table 1 ). The most common fields of research include: assessment of the overall quality of managerial accounting in SMEs; organization of management accounting in the enterprise; analysis of the methods of management accounting that are used; the relationship between the accepted methods of managerial accounting and the volume, type of activity, personal qualities of the manager/owner; the study of the main directions' analysis of management accounting information usage, and the reasons for the refusal of SMEs from the application of management accounting methods.

The results of the research have shown the existence of increasing tendency of the managerial accounting role for SMEs in world practice. Managers/owners wish to receive reliable information about the current situation at the enterprise for the prompt resolution of problems that arise in the decision-making process. With this aim, the management accounting is used in the SMEs and differs in the form of organization, as well as the variety of methods that are used by each country. For example, a study of British scholars has shown that the managerial accounting is made directly by owners - managers in SMEs. They explained their choice by the possibility of direct access to "vulnerable" information presented in the sophisticated form, which

Table 1

Researches' directions of the of management accounting operation at small- and medium-sized enterprises, represented in foreign scientific sources

\begin{tabular}{|c|c|c|c|c|c|c|c|c|c|c|c|}
\hline $\begin{array}{c}\text { Researches' directions of the management } \\
\text { accounting (MA) operation at small- and } \\
\text { medium-sized enterprises }\end{array}$ & 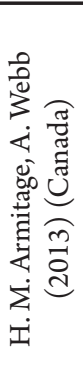 & 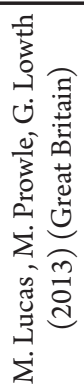 & 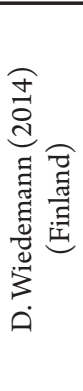 & 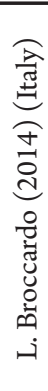 & 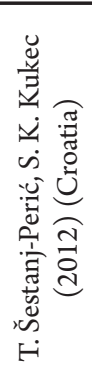 & 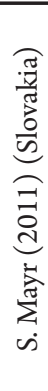 & 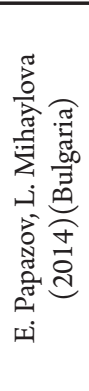 & 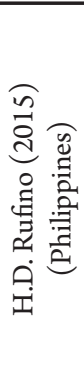 & 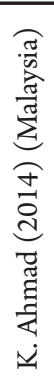 & 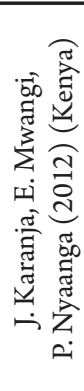 & 푱 \\
\hline 1. Overall quality assessment of the MA in SMEs & + & + & + & + & + & + & + & + & + & + & 10 \\
\hline 2. Organization of the MA & & + & + & & + & + & + & & & & 5 \\
\hline 3. Analysis of the MA methods that are used & + & + & + & + & + & + & & + & + & + & 9 \\
\hline \multicolumn{12}{|l|}{$\begin{array}{l}\text { 4. The relationship between accepted methods } \\
\text { of MA and: }\end{array}$} \\
\hline - the size of SMEs; & + & + & & + & & + & & & + & & 5 \\
\hline $\begin{array}{l}\text { - type of the activity (productive/non- } \\
\text { productive); }\end{array}$ & + & + & & + & & & & + & + & & 5 \\
\hline - organizational and legal form; & & & & & & + & & & & & 1 \\
\hline - personality features of the manager; & & + & & & + & & + & & + & & 4 \\
\hline - involvement of external consultants; & & & + & & + & & + & & & & 3 \\
\hline - ways of financing; & & + & & & + & & & & & & 2 \\
\hline - investments; & & & & + & & & & & & & 1 \\
\hline - the orientation towards foreign markets. & & & & + & + & + & & & & & 3 \\
\hline $\begin{array}{l}\text { 5. Investigation of the main sources of } \\
\text { information acquisition for making managerial } \\
\text { decisions }\end{array}$ & & & & & & & + & & & & 1 \\
\hline $\begin{array}{l}\text { 6. The main directions' analysis of MA } \\
\text { information usage }\end{array}$ & + & + & + & & & & & + & + & & 5 \\
\hline $\begin{array}{l}\text { 7. Reasons for the refusal of SMEs from } \\
\text { the application of management accounting } \\
\text { methods }\end{array}$ & + & + & & & & & + & + & & + & 5 \\
\hline
\end{tabular}

Source: compiled by the author according to the research results 
allows them better understand what is taking place and, therefore, provides the wider control over the enterprise activities. Therefore, they are not inclined to engage accountants specializing in managerial accounting for this work. A similar situation has arisen in the hotel "Rantalina" (Finland), where managerial accounting was not provided by a qualified accountant-analyst of accounting but only by a manager (Wiedemann, 2014). Research of Slovak scholars indicates that in less than $5 \%$ of SMEs exists a separate management accounting unit (Mayr, 2011), while 22\% of Croatian SMEs receive the advisory services related to management information from specialized accounting firms (external consultants), that promote a wider use of management accounting techniques at these enterprises (SestanjPerić \& Kukec, 2012).

A significant influence on the use of management accounting information has a kind of activity. According to the Canadian scholars' research the percentage of usage the management accounting tools in manufacturing firms is higher than in non-productive (Armitage \& Webb, 2013). The sample of the scientists' survey (L. Broccardo (2014) (Italy), H. Rufino (2015) (Philippines), K. Ahmed (2014) (Malaysia)) consisted only of manufacturing SMEs that confirms the higher activity of managerial accounting introduction in the practice of this enterprises group. British scholars also emphasize the relationship of activity's kind with certain management accounting methods (budgeting, CVP analysis) since it influences the ability to revenue and expenditures forecast with a sufficient level of accuracy (Lucas, Prowle \& Lowth, 2013).

In the practice of foreign scientists, the object of research is the process of conducting the management accounting at small- and medium-sized enterprises, but in some countries (like Italy) microenterprises are also distinguished (Broccardo, 2014). Therefore, one of the research directions is the study of the relationship between volume and level of management accounting methods' application. The results of most studies have shown that management accounting practices are more acceptable in medium-sized enterprises. In the case when the number of using methods at small-and medium-sized enterprises coincides, then at medium-sized enterprises they are applied at a higher level. For example, a study of L. Broccardo (2014) (Italy) shows that accounting tools are used by $74 \%$ of microenterprises, $90 \%$ of small and $92 \%$ of medium-sized enterprises; then most of these microenterprises (30\%) have used 4-6 methods of management accounting, while $40 \%$ of small and $46 \%$ of medium-sized enterprises have used nearly 7-9 tools.

The quantitative and qualitative level of conducting the management accounting techniques has been significantly increased in conditions of the availability of economic education or specialized training, seminars hold by SMEs owner or manager, his participation in the process of preparation of management information; the need for attracting bank loans or the founders' requirements for the compilation and submission the management reporting for their consideration; the volume of investment in various enterprise fields, and the orientation of SMEs to trade in foreign markets. All these aspects could be confirmed by the studies' results of: K. Ahmad (Malaysia), L. Broccardo (Italy), D. Wiedemann (Finland), S. Kukec (Croatia), G. Lowth (Great Britain), M. Lucas (Great Britain), L. Mikhaylova (Bulgaria), E. Papazov (Bulgaria), M. Prowle (Great Britain), T. Šestanj-Perić (Croatia).

It should be emphasized that the study of methods and tools of managerial accounting on selected SMEs is the important direction of the research. Since researchers have used the different volumes of a sample of SMEs, then, for a comparison, we divide the SMEs into five groups, depending on the positive answer concerning the use of a particular method or management accounting tool, with the assignment to each group the rank on a five-point scale. The summarized data on the use of methods and tools of management accounting at foreign enterprises are presented in Table 2.

The results of the research have shown that most of SMEs use: typical costing systems (Process Costing, JobOrder Costing), Standard Costing system, Operating Budgets, Cost-Volume-Profit (CVP) Analysis, and Financial Statement Analysis. Meanwhile, less share of SMEs uses the Variable Costing system, Responsibility Accounting, Capital Budgets' Conducting. Taking into consideration the strategic accounting methods, the most common are SWOT-Analysis, Target Costing, Benchmarking, Activity-based Costing and Performance Measurement System. By comparing the level of usage of the operational and strategic management accounting methods, parity is maintained among them.

An analysis of the Asian scholars' researches (Rufino, 2015 \& Ahmad, 2014) has shown that the introduction of management accounting practices is beneficial in terms of using the obtained information for pricing, planning, controlling, productivity evaluating, optimizing the resources' usage, managing, and reducing of the costs, contributes to making decisions on production, sales and marketing. British scholars have come to the conclusion that management accounting is typically used not for decision support but for managerial controlling (Lucas, Prowle \& Lowth, 2013). Croatian scholars point out that the use of managerial accounting information helps to overcome internal weaknesses of SMEs and, accordingly, better adapt to dynamic environment conditions (Šestanj-Perić \& Kukec, 2012).

The main reasons for the refusal of SMEs from the application of management accounting methods are: significant money and time expenditures for conducting the practice of management accounting; lack of qualified personnel, trainings and seminars; the type of activity and the number of business operations that would allow using all known methods of managerial accounting. 
Table 2

The main methods and tools of managerial accounting used at small- and medium-sized foreign enterprises

\begin{tabular}{|c|c|c|c|c|c|c|c|c|c|c|}
\hline № & $\begin{array}{l}\text { Methods and tools of } \\
\text { managerial accounting }\end{array}$ & 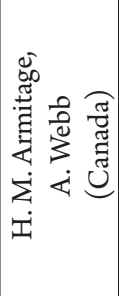 & 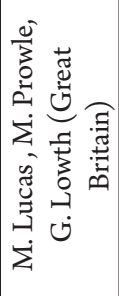 & 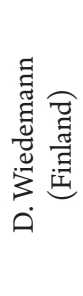 & 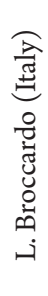 & 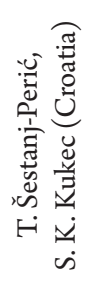 & 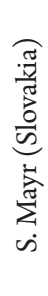 & 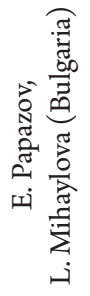 & 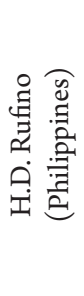 & 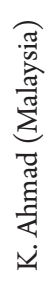 \\
\hline 1. & $\begin{array}{l}\text { Typical costing systems } \\
\text { (Process Costing, Job-order Costing) }\end{array}$ & 4 & 5 & 5 & 5 & 4 & $\mathrm{X}$ & $\mathrm{X}$ & 2 & 5 \\
\hline 2. & Standard Costing system & 3 & 5 & $\mathrm{X}$ & $\mathrm{X}$ & 4 & $\mathrm{X}$ & 5 & 1 & $\mathrm{X}$ \\
\hline 3. & Variable Costing system & 4 & - & $\mathrm{X}$ & $\mathrm{X}$ & 1 & $\mathrm{X}$ & 2 & 2 & $\mathrm{X}$ \\
\hline 4. & Quality Cost system & 2 & - & $\mathrm{X}$ & $\mathrm{X}$ & $\mathrm{X}$ & $\mathrm{X}$ & $\mathrm{X}$ & $\mathrm{X}$ & $\mathrm{X}$ \\
\hline 5. & Target Costing system & 2 & - & - & $\mathrm{X}$ & $\mathrm{X}$ & 1 & 3 & 3 & 2 \\
\hline 6. & Activity Based Costing & 1 & - & - & $\mathrm{X}$ & - & $\mathrm{X}$ & 1 & 3 & 1 \\
\hline 7. & Kaizen Costing system & $\mathrm{X}$ & - & $\mathrm{X}$ & $\mathrm{X}$ & $\mathrm{X}$ & 2 & $\mathrm{X}$ & $\mathrm{X}$ & \\
\hline 8. & SWOT-Analysis & $\mathrm{X}$ & $\mathrm{X}$ & 5 & $\mathrm{X}$ & 2 & 3 & 3 & $\mathrm{X}$ & $\mathrm{X}$ \\
\hline 9. & "Just-in-time" system & $\mathrm{X}$ & $\mathrm{X}$ & $\mathrm{X}$ & $\mathrm{X}$ & $\mathrm{X}$ & $\mathrm{X}$ & 3 & $\mathrm{X}$ & 1 \\
\hline 10. & Benchmarking & $\mathrm{X}$ & - & - & $\mathrm{X}$ & 4 & 3 & 4 & 3 & $\mathrm{X}$ \\
\hline 11. & Operating Budgets & 5 & 3 & - & 4 & $\mathrm{X}$ & 3 & 4 & 4 & $\mathrm{X}$ \\
\hline 12. & Capital Budgets & 3 & $\mathrm{X}$ & - & 4 & $\mathrm{X}$ & 1 & $\mathrm{X}$ & 4 & $\mathrm{X}$ \\
\hline 13. & Flexible Budgets & 1 & $\mathrm{X}$ & - & $\mathrm{X}$ & $\mathrm{X}$ & $\mathrm{X}$ & $\mathrm{X}$ & 1 & $\mathrm{X}$ \\
\hline 14. & Zero Base Budgeting & $\mathrm{X}$ & $\mathrm{X}$ & - & $\mathrm{X}$ & $\mathrm{X}$ & $\mathrm{X}$ & - & 3 & $\mathrm{X}$ \\
\hline 15. & Responsibility Accounting & 4 & 3 & $\mathrm{X}$ & $\mathrm{X}$ & $\mathrm{X}$ & $\mathrm{X}$ & 2 & $\mathrm{X}$ & $\mathrm{X}$ \\
\hline 16. & Balanced Scorecard system & - & - & - & $\mathrm{X}$ & 1 & 1 & 1 & $\mathrm{X}$ & $\mathrm{X}$ \\
\hline 17. & Product Lifecycle Analysis & $\mathrm{X}$ & - & - & $\mathrm{X}$ & 2 & $\mathrm{X}$ & $\mathrm{X}$ & 3 & $\mathrm{X}$ \\
\hline 18. & Cost- Benefit Analysis & $\mathrm{X}$ & $\mathrm{X}$ & - & $\mathrm{X}$ & $\mathrm{X}$ & 1 & $\mathrm{X}$ & $\mathrm{X}$ & $\mathrm{X}$ \\
\hline 19. & Variance Analysis & 5 & - & - & 4 & $\mathrm{X}$ & $\mathrm{X}$ & 4 & 4 & $\mathrm{X}$ \\
\hline 20. & Cost-Volume-Profit (CVP) Analysis & 2 & 5 & - & 3 & $\mathrm{X}$ & $\mathrm{X}$ & 4 & 3 & $\mathrm{X}$ \\
\hline 21. & Working Capital Measures & $\mathrm{X}$ & 5 & $\mathrm{X}$ & $\mathrm{X}$ & $\mathrm{X}$ & $\mathrm{X}$ & $\mathrm{X}$ & $\mathrm{X}$ & $\mathrm{X}$ \\
\hline 22. & Cash Flow Analysis & 1 & - & - & 4 & $\mathrm{X}$ & $\mathrm{X}$ & 5 & $\mathrm{X}$ & $\mathrm{X}$ \\
\hline 23. & Overhead Analysis & 4 & - & - & 4 & - & $\mathrm{X}$ & $\mathrm{X}$ & $\mathrm{X}$ & $\mathrm{X}$ \\
\hline 24. & Performance Measurement System & 5 & $\mathrm{X}$ & 5 & $\mathrm{X}$ & $\mathrm{X}$ & 3 & $\mathrm{X}$ & 4 & $\mathrm{X}$ \\
\hline 25. & $\begin{array}{l}\text { Formation of the non-financial } \\
\text { Information }\end{array}$ & $\mathrm{X}$ & $\mathrm{X}$ & 5 & $\mathrm{X}$ & 5 & $\mathrm{X}$ & $\mathrm{X}$ & $\mathrm{X}$ & $\mathrm{X}$ \\
\hline 26. & Financial Statement Analysis & 5 & $\mathrm{X}$ & $\mathrm{X}$ & 5 & 5 & $\mathrm{X}$ & 5 & $\mathrm{X}$ & $\mathrm{X}$ \\
\hline 27. & Statistical Analysis & $\mathrm{X}$ & $\mathrm{X}$ & $\mathrm{X}$ & $\mathrm{X}$ & $\mathrm{X}$ & $\mathrm{X}$ & 3 & $\mathrm{X}$ & $\mathrm{X}$ \\
\hline 28. & Multiple Regression & $\mathrm{X}$ & $\mathrm{X}$ & $\mathrm{X}$ & $\mathrm{X}$ & $\mathrm{X}$ & $\mathrm{X}$ & - & $\mathrm{X}$ & $\mathrm{X}$ \\
\hline 29. & Net Present Value (NPV) Analysis & $\mathrm{X}$ & - & - & $\mathrm{X}$ & 2 & 1 & - & 3 & $\mathrm{X}$ \\
\hline
\end{tabular}

Abbreviation concerning the use of a certain method of managerial accounting with the assignment to each group the rank on a five-point scale: "1" - the method of managerial accounting is used by 1-19\% of the SMEs from the sample; " 2 " - 20-39\% of SMEs; " 3 " - 40-59\% of SMEs; "4" - 60-79\% of SMEs; "5" - 80-100\% of SMEs; "-" - the method of management accounting is not used by SMEs; "X" - the usage of the management accounting method was not the subject of the research.

Source: compiled by the author according to the research results

Consequently, according to the analysed studies, we may confirm the feasibility of introducing of management accounting subsystem into the accounting system of a small enterprise. The conducting of management accounting in foreign SMEs proves the possibility of using some of these instruments at domestic small enterprises. For this purpose, it is necessary to develop an organization procedures and the methodology of conducting the managerial accounting in practice, which have already been partially done by Ukrainian scientists.
4. The investigation of the management accounting organization at small enterprises in the Lviv region (methodology of the survey)

The main goal of the study was to test the existing position of the accounting system of the small enterprises in Ukraine. Among the main directions of its achievement was the study of the management accounting tools using. The survey was conducted in the form of an interview with the manager/chief accountant/financial director of a small business or by 
Table 3

Stages of investigation of the management accounting organization at a small enterprise

\begin{tabular}{|c|c|c|}
\hline \multicolumn{2}{|c|}{$\begin{array}{l}\text { Stages of investigation of the management accounting } \\
\text { organization at a small enterprise }\end{array}$} & \multirow[t]{2}{*}{ Characterization of the received information } \\
\hline Number of stage & Name of stage & \\
\hline First stage & $\begin{array}{l}\text { Information for management } \\
\text { decision-making }\end{array}$ & $\begin{array}{l}\text { - the main sources and types of information used by the head of a small } \\
\text { enterprise; } \\
\text { - periodicity of the information submission; } \\
\text { - employees involved in its preparation. }\end{array}$ \\
\hline Second stage & $\begin{array}{l}\text { Practice of conducting the } \\
\text { management accounting }\end{array}$ & $\begin{array}{l}\text { - information about methods of cost accounting and calculating the cost of } \\
\text { production; } \\
\text { - tools of operational and strategic management accounting; } \\
\text { - factors that have contributed to the use of management accounting at small } \\
\text { enterprises. }\end{array}$ \\
\hline Third stage & $\begin{array}{l}\text { Reasons for the refusal from the } \\
\text { management accounting and } \\
\text { organization of management } \\
\text { accounting }\end{array}$ & $\begin{array}{l}\text { - the main reasons for the refusal from management accounting at small } \\
\text { enterprises or the insufficient use of its tools; } \\
\text { - definition of the persons who should be engaged in its introduction; } \\
\text { - methods and techniques of managerial accounting that should be used } \\
\text { in the case of organization the management accounting subsystem at small } \\
\text { enterprises. }\end{array}$ \\
\hline
\end{tabular}

Source: compiled by the author according to the research results

sending to these persons the questionnaire by e-mail for filling it. The sample included fifty-five small enterprises of different types of activities and forms of ownership. The data collection was carried out on the basis of the questionnaire developed by us, which consists of the following five sections:

I. General data on a small business.

II. The organizational structure of small business and form of management.

III. Organization of accounting.

IV. Organization of financial accounting.

V. Organization of management accounting.

The survey, which was conducted on the basis of the questions from five section of the questionnaire "Organization of the management accounting system", can be divided into three stages (see: Table 3).

\section{The results of the study}

Analysis of the main manager's information sources with the aim of making managerial decisions was conducted on the basis of the respondent's choice of one (or several) in three variants of reporting used by the small enterprise. Among them: operational reports, which involves the information about the operating activities of the enterprise (supply, manufacture, sale) and can be presented in tabular form, as well as in the form of reports or notes; financial statements, drawn up by small enterprises in accordance with the current legislation; responsibility accounting reports, which include the activity indicators that are affected by the employees of the particular centre.

According to the results of the study, it is defined that making the managerial decision on the base of operational reports are conducted at 29 small domestic enterprises, as well as on the base of financial statements - 10 enterprises, then by using the responsibility accounting reports - only at one small enterprise. Operational reports in combination with the financial statement are the source of information for management in 13 enterprises, while the indicators of these three types of reporting are used only at one small enterprise. Therefore, the main information source in the management of the small business is operational reporting.

Considering the periodicity of collecting the information about the activity at a small enterprise for the manager/owner, it is found that this information is daily submitted in 19 enterprises, once a week - in 16 enterprises, 2-3 times per month - in 4 enterprises, 1 time per month - in 18 small enterprises. So, the largest percentage $(34.5 \%)$ of enterprises has daily prepared the information for a manager. However, it should be noted that for the vast majority of enterprises with different intervals of information providing, the time range is within one month.

A chief accountant (outsourcer) or manager carried out the preparation of business activities' information in most of the small enterprises. The share of such enterprises is $56.4 \%(12.7 \%)$ and $27.3 \%$ accordingly. The post of accounting analyst is provided in 3 small enterprises, and then the preparation of information for the manager by the financial director is provided also in 3 of SMEs. Respondents of some (4 entities) small enterprises said that collection and processing of information are provided by the chief accountant and manager or chief accountant and chief financial director.

In order to secure a competitive position in the market managers of small businesses have to use a variety of information characterized the business activity. This information can be obtained by analysing the indicators of financial reporting, non-financial 
indicators or analytical information received on the basis of methods and techniques of management accounting. Results of the study represent that the majority of small enterprises (30 entities) uses different combinations of two indicators' types for making management decisions, the main part of which are non-financial indicators and analytical information obtained on the base of management accounting methods (13 entities). Non-financial indicators and the indicators of the financial statement are used at 10 small enterprises, while the indicators of financial statement combined with analytical information - only at 7 small enterprises. Furthermore, 7 small enterprises use for the management a combination of three mentioned indicators above. Among enterprises that use only one indicator - the most popular is decision-making based on non-financial indicators $(43.6 \%)$.

The second stage of the study "Practice of conducting the management accounting" showed that cost of production calculation at most small enterprises is carried out by Full Cost Method (52.7\%), according to Ukrainian Accounting Standards no. 16 and by Job-order Costing (45.5\%). Only two enterprises from sample provide Responsibility Accounting, and seven entities use Budgeting. The most popular types of analysis are Marginal Analysis and Cost-Benefit Analysis. Therefore, two small enterprises use all four types of analysis, while one enterprise has used three types (marginal analysis, analysis of alternative solutions and analysis of resource use in the presence of constraints). Five enterprises use different combinations of these two types and twentytwo entities use only one kind of analysis. Regarding the use of methods and techniques of strategic management accounting, the most common is the Analysis of Competitors (51.1\%) and Target Calculation (21.3\%). Most of the small enterprises use only one method (18), a combination of two methods - 10 units, three methods -3 units. The main factors influencing the use of management accounting techniques are the manager willingness and the objective need to improve the financial position of the enterprise.

According to the third stage of the study "Reasons for the refusal from the management accounting and organization of management accounting" it is defined that the main factor of the non-use or use the lowlevel management accounting methods is significant money and time expenditures for its organization and management. Otherwise, the manager and accountants of four small enterprises have a sceptical opinion to the management accounting introduction for this category of business entities. The majority of respondents replied that in the case of management accounting organization at the small enterprise, it should be carried by a chief accountant (outsourcer) or an accountant-analyst. In most small enterprises, where management accounting is not used or used at a low level, it is expedient to introduce such methods as: Cost-Benefit Analysis, Cost-
Volume-Profit (CVP) Analysis, Analysis of Alternative Solutions, Budgeting and SWOT-Analysis.

Consequently, according to the results of the study obtained on the basis of first stage questions "Information for making managerial decisions", we can conclude that the main source of information for the manager in the process of managerial decisionmaking is the operational reports or their combination with the financial assessment. The preparation of such information is made by Chief Accountant (outsourcer), who submits it to the manager daily, once per week or once per month. The indicators of financial reporting, analytical information, obtained on the base of management accounting methods, as well as nonfinancial indicators that characterize the economic activities of a small enterprise, are the basis for managers in managerial decision-making.

The results of the second stage "Practice of conducting the management accounting" show that in order to improve the financial position of small enterprises, their managers use information derived from the application of methods of operational and strategic management accounting. However, the level of their implementation is rather low since most small entities use only one of the methods of operational and strategic management accounting. It should be also emphasized that the number of management accounting methods used by small enterprises is higher if the founders are foreign citizens and/or whose average number of employees exceeds 30 persons.

Significant money and time expenditures for the organization and conducting of the management accounting are the main reason for the refusal to use it at small enterprises, due to the results of the third phase of the research "Reasons for the refusal from the management accounting and organization of management accounting". Otherwise, most of the small enterprises have an understanding of the benefits from using management accounting, do not deny the expediency of its organization and determine the methods of managerial accounting, which will help to improve their financial situation. After all, the main reasons for the deterioration of the financial situation of small enterprises are: a) cash deficit (low liquidity); b) insufficient return on equity (low ROE); c) lack of an appropriate level of financial situation (low profitability); d) inefficient management of financial resources.

We have to note that problems of small enterprises related to solvency, profitability, and financial independence have a unified framework characterized by the lack of an appropriate methodological basis for forecasting the indicators of break-even and profitable activity, the lack of the efficient calculation system and use of other managerial accounting tools. As a result, there appears a need to improve the financial situation of small enterprises in the Lviv region by 
optimizing the costs and revenues through structuring the sources of revenues' formation and directions of its using with a distinguishing the percentage of revenue on reinvestment; by efficient resources use in order to rationalizing the inventories management; by carrying out the analysis and redistribution of assets for the detection of negative phenomena of influence; by financial risks reduction and by financial stability increasing.

\section{Conclusions}

The results of the study confirmed that a sufficient part of the management informational support at small enterprises of Lviv region is the information obtained by the use of methods and techniques of managerial accounting. However, we can observe a low level of their application. Therefore, there appears a need to ensure the awareness of managers on the benefits of using different management accounting methods that can be achieved by attending specialized courses, trainings or seminars conducted on the basis of higher education institutions. This, in turn, enhances the role of scientists in creating a theoretical framework of managerial accounting for small business entities and mechanisms of implementing it in practice.

Consequently, in order to improve the financial situation of small enterprises, it is expedient to use anti-crisis measures, which secure from the crisis and financial problems, as well as reduce the risk level. The main anti-crisis measures are: reduction or optimization of costs, effective use of marketing and staff personnel policies, timely staged planning, well-organized budgeting, etc. The success of anti-crisis measures application will be achieved in case of their use at each stage of the company's life cycle. In particular, at the stage of enterprise establishing should be clearly defined a strategy of product promotion on the market, as well as pricing and communication strategy. At the stage of the company lifting, it is recommended to think about preventing a crisis situation by using an effective and professional management system and if it is necessary the attraction of skilled professionals. At the stage of maturity - the purpose of the anti-crisis measures' application is to stabilize the situation and prevent the reduction of the market segment. The stage of reorganization or bankruptcy is characterized by the use of measures aimed at optimizing budgeting (if necessary - renting an unusual space, selling individual buildings, etc., or favourable selling of the company). Successful implementation of the above-mentioned stages is possible under the condition of proper organization of strategic management accounting at small enterprises but the survey of respondents shows that the development of strategic accounting at domestic small enterprises is only on the initial stage.

\section{References:}

Ahmad, K. (2014). The Adoption of Management Accounting Practices in Malaysian Small and Medium-Sized Enterprises. Asian Social Science, 10(2): 236-249.

Armitage, H.M., Webb, A. (2013). The Use of Management Accounting Techniques by Canadian Small and Medium Size Enterprises: A Field Study. CAAA Annual Conference 2013. Retrieved from: http://papers.ssrn.com/ sol3/papers.cfm?abstract_id=2201163

Broccardo, L. (2014). Management Accounting System in Italian Smes: Some Evidences and Implications. Advances in Management \& Applied Economics, 4(4): 1-16.

Chernelevskyy, L. (2003). Satisfaction of Modern Management Needs in Accounting Information. Accounting and Auditing, 3: 21-22.

Denga, S.M. (2007). Organization of Management Accounting in the Conditions of Computerization. Retrieved from: https://goo.gl/zdXDAw

Drobyazko, S.I. (2013). Organization of Management Accounting in Small Business Enterprises. Economy. Finances. Law: Informational and Analytical Magazine, 2: 68-70.

Gogol T.A. (2014). Accounting and Analytical Support in the Management of Small Enterprises: A Monograph. Chernihiv: Publisher Lozovyy V.M., 384.

Karanja, J, Mwangi, E., Nyaanga, P. (2012). Adoption of Modern Management Accounting Techniques in Small and Medium (SMEs) in Developing Countries: A Case Study of SMEs in Kenya. Retrieved from: https://goo.gl/ BNwwp8

Levytska, S.O. (2007). Methodology of Organization and Prospects of Management (Internal) Accounting Development. University Scientific Notes, 3 (23): 245-253.

Lucas, M., Prowle, M., Lowth, G. (2013). Management Accounting Practices of (UK) Small-Medium-Sized Enterprises (SMEs). Improving SME performance through Management Accounting Education, 61(6): 13.

Lymonova, E.M. (2005). Information as a Component of Controlling in a Small Enterprise. Academic Review, 2 : 80-82.

Mayr, S. (2011). The Organization of Management Accounting in Slovakia in Small and Medium Size Enterprises. Paper presented at The 1th REDETE Conference "Economic Development and Entrepreneurship in Transition Economies: A Review of Current Policy Approaches”: Banja Luka, 73-81. 
Niporko, N.I. (2015). The Formation of Accounting System on a Small Enterprise: Managerial Aspect. Problems and Prospects of Economy and Management, 4: 377-384.

Ocheret'ko, L.M., Krasnovska, N.V. (2017). Organization of Management Accounting at the Enterprises of Small Business. Sustainable Growth of Economics, 1(34): 88-94.

Papazov, E., Mihaylova, L. (2014). Linking Accounting Information with Business Planning in Bulgarian SMEs. Proceeding of The 8th International Management Conference "Management Challenges for Sustainable Development”: Bucharest, 321-327.

Rufino, H.D. (2015). Management Accounting Practices (MAPs) of Small and Medium-Sized Manufacturing Enterprises in The City of Tarlac. Review of Integrative Business and Economics Research, 4(1): 55-74.

Šestanj-Perić, T., Kukec, S.K. (2012). The Application of Management Accounting (Controlling) Instruments in Small and Medium-Size Enterprises in Nord-Western Croatia. Retrieved from: https:/ /bib.irb.hr/datoteka/612612. Article_ARSA_Sestanj_Peric_Kukec.pdf

Slosko, T. (2006). Management Accounting or Management Strategy. Accounting and Auditing, 2: 49-54.

Wiedemann, D. (2014). Characteristics of Management A goo.gl/vaDrNUccounting in Small and Medium-Sized Enterprises. Case: Rantalinna Oy. Retrieved from: goo.gl/1keMTz

\section{Надежда ХОЧА}

\section{ОРГАНИЗАЦИЯ УПРАВЛЕНЧЕСКОГО УЧЕТА НА МАЛЫХ ПРЕДПРИЯТИЯХ В УКРАИНЕ}

Аннотация. Целью работы является исследование состояния организации управленческого учета на малых предприятиях в Украине. Методология. Опросы о состоянии управленческого учета проводились путем проведения интервью с руководителем/главным бухгалтером/финансовым директором малого предприятия или передачей указанным должностным лицам анкет на их электронную почту для самостоятельного заполнения. Выборка составила пятьдесят пять малых предприятий Львовской области различных видов деятельности и форм собственности. Результаты. Изучение теоретических наработок украинских ученых и опыта применения управленческого учета на малых предприятиях за рубежом позволило выделить три основных этапа исследования. По итогам опроса первого этапа "Информация для принятия управленческих решений" делаем выводы, что основным источником информации для руководителя, при принятии управленческих решений, являются оперативные отчеты (или их сочетание с финансовой отчетностью), подготовкой такой информации занимается главный бухгалтер (аутсорсер) и представляет ее руководителю ежедневно, один раз в неделю или месяц. Показатели финансовой отчетности, аналитическая информация, полученная на основе использования методов управленческого учета и нефинансовые показатели, характеризующие хозяйственную деятельность малого предприятия, являются основой для руководителей при принятии управленческих решений. Результаты исследования второго этапа "Практика ведения управленческого учета" показывают, что с целью улучшения финансового состояния малых предприятий, их руководители используют информацию, полученную на основе применения методов оперативного и стратегического управленческого учета. Однако уровень их внедрения является достаточно низким, поскольку на большинстве малых предприятий используют только один из методов оперативного и стратегического управленческого учета. Также отметим, что количество применяемых методов управленческого учета является выше на малых предприятиях, учредителями которых являются иностранные граждане и/или среднее количество работников которых превышает 30 человек. Значительные затраты денег и времени на организацию и ведение управленческого учета являются основной причиной отказа от его использования на малых предприятиях, о чем свидетельствуют результаты опроса третьего этапа исследования «Причины отказа и организация управленческого учета". Однако на большинстве малых предприятий, понимая преимущества использования управленческого учета, не отрицают целесообразности его организации и определяют методы управленческого учета, применение которых будет способствовать улучшению их финансового состояния. Практическая реализация. По результатам исследования сделан вывод, что на малых предприятиях составляющей информационного обеспечения управления является информация, полученная на основе использования методов и инструментов управленческого учета. Однако наблюдаем низкий уровень их применения. Поэтому возникает потребность в проведении на базе высших учебных заведений специализированных курсов, тренингов или семинаров с целью информирования руководителей малыхпредприятий опреимуществахприменения различныхметодов управленческогоучета. Значение/оригинальность. Полученные результаты являются основой создания теоретической базы управленческого учета для украинских субъектов малого предпринимательства и механизмов внедрения ее на практике. 